\title{
ETNOTOPOGRAFIA APLICADA EM PRAÇAS: ALGUMAS FERRAMENTAS PARA LER A CIDADE EM ARQUITETURA E URBANISMO
}

\author{
Paolla Clayr de Arruda Silveira ${ }^{1}$
}

\begin{abstract}
RESUMO
SILVEIRA, P. C. A. Etnotopografia aplicada em praças: algumas ferramentas para ler a cidade em arquitetura e urbanismo. Perspectivas Online: Humanas \& Sociais Aplicadas, v.10, n.27, p.1 -21, 2020.

Os textos não-verbais acompanham as caminhadas pela cidade, produzem-se, completam-se, alteram-se ao ritmo dos passos e, sobretudo, da capacidade de perceber, de registrar essa informação: transforma os textos não verbais em marcos referenciais da cidade, que aglutinam objeto e signo urbanos. $\mathrm{O}$ que se propõe neste trabalho é traçar um método de análise da Praça São Salvador, centro histórico da cidade, referencial numa área comercial de intenso fluxo de pessoas, de diversos lugares do município e adjacências. O objetivo é reconhecer os elementos estruturantes dos discursos de duas praças através da produção de sentidos no usuário na cidade de Campos dos Goytacazes, diante de uma abordagem

Caminhando pelo processo de formação histórico-espacial dos espaços públicos e na sua contextualização na imagem da cidade, permeando pela temática da característica de palimpsesto do espaço urbano e na condição topofílica do espaço arquitetural, avistam-se percursos metodológicos interdisciplinares, unindo arquitetura, semiótica, análise do discurso e psicologia nessa busca pelos elementos atuantes na produção de sentidos na arquitetura, logo, no processo semântico das praças urbanas, denominado Etnotopografia, numa proposta para a leitura do espaço nãoverbal, aplicável às habilidades profissionais de arquitetos e urbanistas, provocando resultados surpreendentes.
\end{abstract} prática das discussões semiológicas.

Palavras-chave: Discurso; Semiótica; Arquitetura; Cidade; Percepção. 


\begin{abstract}
Non-verbal texts accompany walking around the city, take place, complete themselves, change with the pace of the steps and, mainly, the ability to perceive, record this information: it transforms non-verbal texts into the city's landmarks, which agglutinate urban object and sign. What to apply in this work is to track a method of analysis of Praça São Salvador, the historic center of the city, a reference in a commercial area with intense flow of people, different places in the city and surroundings. The objective is to recognize the structured elements of the speeches of two squares through the production of meanings in the user in the city of Campos dos Goytacazes, in view

discussions. Walking through the process of historical-spatial training of public spaces and their contextualization in the image of the city, permeating the theme of urban space resources and the topographic conditions of the architectural space, there are interdisciplinary methodological paths, uniting architecture, semiotics, discourse analysis and psychology in this search for elements active in the production of meanings in architecture, logo, semantic process of urban squares, called Ethnotopography, in a proposal to read nonverbal space, applying it to the professional skills of architects and urban planners, causing surprising results.
\end{abstract} of a practical approach to the semiological

Keywords: Discourse; Semiotics; Architecture; City; Perception.

\footnotetext{
${ }^{1}$ Instituto Federal de Educação, Ciência e Tecnologia Fluminense - IF Fluminense Campos Centro - Coordenação de Arquitetura e Urbanismo - Rua Dr. Siqueira, 273, Parque Dom Bosco, Campos dos Goytacazes, RJ, CEP: 28030-130, Brasil. (*) e-mail: paolla.silveira@iff.edu.br

Data de recebimento: 08/07/2019. Aceito para publicação: 17/02/2020
}

Persp. Online: hum \& sociais aplicada., Campos dos Goytacazes, 27 (10)1-21- 2020 seer.perspectivasonline.com.br 


\title{
1. INTRODUÇÃO
}

Segundo Santaella (2007), há uma linguagem verbal, representada na escrita e na fala, mas ocorrem, concomitantemente, outras linguagens, também constituídas por sistemas sóciohistóricos de representação. Neste trabalho, será abordada a linguagem do espaço urbano, em busca dos estruturantes de seus dizeres e significações. $\mathrm{O}$ viés discursivo do contexto urbano tem contribuído de maneira significativa para as análises dos conteúdos inscritos no discurso sobre cidade e de seus espaços e sujeitos que a animam, por meio do discurso não-verbal, que colabora para com a semantização do espaço.

Cada ponto do espaço urbano, como suas vias, construções, terrenos baldios ou semiconstruídos, contribuem para a formação de uma malha informacional. O caminhar pela cidade assemelha-se a navegar por um hipertexto, que permite diversas associações significantes, promovendo uma leitura multilinear, pautada no percurso e não mais no plano representativo. Segundo Ferrara (1986), o contexto espacial abarca o conjunto de circunstâncias físicas, sociais, econômicas e culturais subjacentes ao uso ambiental, que, por interferência e não determinação dessas variáveis, é múltiplo e diversificado. Nessa perspectiva, a cidade constitui-se como um grande texto a ser lido/interpretado/compreendido por aqueles que estruturam a sua corporeidade.

\begin{abstract}
Sendo assim, aproximar-se da Interdisciplinaridade é construir utopias na prática para reconstruir o que o sistema fragmenta e oprime; viver a interdisciplinaridade e não simplesmente praticá-la como "caixas de conteúdo", o que exige amplo sentido de entrega de si e preenchimento do outro. Construir a interdisciplinaridade como atitude pedagógica possibilita também a aproximação, cuja atitude está carregada de sentido epistemológico e não configura-se na superficialidade da repetição, da aplicação, mas na busca pela constante inquietação que nos motiva a saber, que não se cabe em si, da dúvida que se problematiza e das múltiplas "disciplinas" que não se encerram, mas que diuturnamente, se (re)constroem através do diálogo transversal (MANHÃES, 2018, p. 1).
\end{abstract}

O olhar deste trabalho se volta à Etnotopografia como percurso metodológico, em busca de elementos que formam o discurso sobre as cidades, especialmente em espaços urbanos como as praças, exemplificado neste artigo pela Praça São Salvador, em Campos dos Goytacazes-RJ - que permite intensas e frequentes trocas, nem sempre possíveis em espaços particulares.

\section{METODOLOGIA}

Ferrara (1986, p. 30) questiona: "Como ler? Como ensinar a ler o não-verbal? Como respeitar e valorizar a dinâmica do espaço ambiental?". Segundo a autora, não há método fixado ou pré-determinado, não sendo método o conceito mais adequado, e sim procedimentos metodológicos, ou seja, "há necessidade de estabelecer esses mecanismos, porém sua operacionalização depende da natureza e da dinâmica de cada objeto lido".

Na perspectiva de Coelho Netto (1984), por ainda não ter sido uma espinha dorsal do espaço arquitetural claramente definida para orientar os trabalhos e delimitar o campo de ação, a proposta, então, é buscar termos efetivamente essenciais na linguagem do espaço arquitetural. Segundo o autor, os eixos organizadores do sentido do espaço arquitetural são:

- espaço interior $\mathrm{x}$ espaço exterior;

- espaço privado x espaço comum;

Persp. Online: hum \& sociais aplicada., Campos dos Goytacazes, 27 (10)1-21- 2020

seer.perspectivasonline.com.br 
- espaço construído x espaço não-construído;

- espaço artificial x espaço natural;

- espaço amplo x espaço restrito;

- espaço vertical x espaço horizontal;

- espaço geométrico x espaço não-geométrico.

O primeiro eixo: espaço interior x espaço exterior demonstra a relevância subjetiva de proteção tanto física quanto psicológica, identificada no espaço interior. Ao mesmo tempo, esse eixo contempla a relação dialógica entre a edificação e a cidade, dando ênfase a tal relação. Essa relação é percebida conforme o histórico cultural do indivíduo que vivencia o lugar, como as cláusulas da burocracia, religião, privilégios e classes sociais.

Já o segundo eixo: espaço privado x espaço comum refere-se aos usos e sentidos diversificados que se atribuem a esse espaço conforme a cultura (ou o grupo social) e a época. A composição dos espaços pode conferir caráter de uso privado ou comum, de maneira a integrar ou segregar pessoas ou classes sociais, e demonstra o espaço arquitetural como reeducador de comportamentos através de uma infraestrutura do espaço.

Quanto ao eixo espaço construído x espaço não-construído, esseestá principalmente associado à participação política, à inclusão ou exclusão dos cidadãos, de modo geral, às mudanças nas necessidades biológicas humanas. Modificações no espaço exterior comum não-construído estão relacionadas a conflitos de classes, mediante as necessidades de segurança e lazer, por exemplo.

A incorporação dialética do não-construído no espaço interior privado (casa pompeana ou egípcia, por exemplo, com seus pátios internos) se mostra a melhor maneira de conviver corpo (cheio) e imaginação (vazio) em equilíbrio, mas por não ser a solução que "melhor aproveita" o espaço, só é acessível a quem pode pagar pelo "desperdício" imobiliário.

O eixo seguinte, o do espaço artificial x espaço natural, vem diluir a ideia de que o natural é apenas a forma original da natureza, sem as modificações do homem. Mostra que a intervenção humana vem para adequar o natural ao uso cotidiano, sem perder sua credibilidade de algo natural. O importante nesse eixo é que o espaço não-construído - seja natural, seja artificial - se integre ao tecido urbano, mantendo suas características de "espaço livre", sem ser esmagada pela verticalidade.

Com relação ao eixo espaço amplo x espaço restrito, não há necessariamente coincidência entre o espaço restrito e o interior, nem entre o espaço amplo e o exterior. Os significados associados ao espaço restrito remetem à noção de proteção e intimidade, mas também ao mistério e ao secreto. $\mathrm{O}$ espaço amplo é normalmente sentido como não protetor, e até mesmo hostil, o homem não sabe lidar com o espaço que não consegue "dominar" visualmente, provocando a angústia do vazio, do infinito. A amplitude, então, é entendida como algo a ser contemplado, e não vivido. Nesse sentido, a arquitetura, que é capaz de submeter o indivíduo ao espaço projetado, deve propor mudanças nesse espaço para adaptá-lo ao bem-estar do usuário.

$\mathrm{O}$ aspecto mais importante do eixo espaço vertical x espaço horizontal é o da temporalidade do espaço. Pela própria natureza material do objeto arquitetônico, o espaço não pode ser modificado constantemente, mas sua vivência pode ser dinamizada, enriquecendo assim a relação entre o homem e o espaço. A alternância entre os planos horizontal e vertical,

Persp. Online: hum \& sociais aplicada., Campos dos Goytacazes, 27 (10)1-21- 2020 seer.perspectivasonline.com.br 
vencendo desníveis, é uma maneira de dinamizar o espaço, possibilitando que seja vivenciado na dimensão temporal, permitindo experimentar, tocar, percorrer, modificando a percepção de opressão, tédio.

Na discussão do último eixo, espaço geométrico x espaço não-geométrico,é ressaltado o fato de que a representação geométrica está vinculada à representação de modelos, entre o abstrato e o concreto. Porém, é necessário livrar-se das algemas geométricas, de ângulos retos, para alcançar espaços mais orgânicos, onde o espaço respira e é informal, permitindo, em cada curva, uma nova perspectiva.

É nesses termos que procederemos a uma leitura parcial da cidade, tendo como baliza as transformações que os dois espaços selecionados para a nossa análise sofreram.

Conforme a explicação de Ferrara (1986, p. 30), ao se tratar de método possível para leitura de espaços não-verbais, como a cidade, deve-se salientar três aspectos:

- Estabelecimento de um modo de ler; que se completa e se refaz a cada leitura, visto que o objeto é dinâmico, capaz de mostrar em si como deve ser lido;

- É necessário ter presente que o observado no objeto lido é resultado de uma operação singular entre o que está no objeto e a memória informacional e experiências emocionais e culturais, individuais ou coletivas; assim, o resultado da leitura é sempre possível, mas jamais correto ou total.

- É necessária ousadia nas associações para se flagrar ideias novas, comparações imprevistas, uma hipótese explicativa inusitada.

Nesse sentido, a proposta para a leitura do espaço não verbal, objeto desta pesquisa, está vinculada às discussões semiológicas em Coelho Netto (1984), que demonstra uma prática da semiologia, aplicável às habilidades profissionais de arquitetos e urbanistas.

Os procedimentos de Coelho Netto (1984) se entremeiam e são balizados, propositalmente ou não, nas considerações de Ferrara (1986, [30]) acerca das possibilidades de análise do texto não verbal, ao habilitar as variáveis "constantes estratégicas e procedimentos des-verbais". Essa similaridade entre os autores será mais bem descrita no decorrer deste tópico.

As constantes estratégicas, subdivisão dos procedimentos metodológicos indicados por Ferrara (1986, p. 31-32), têm o objetivo de destruir os comportamentos automatizados, pois considera que, "assim como não é possível ler o homogêneo, também não é possível ler/ver/perceber o que não conseguimos estranhar". Entretanto, o absolutamente novo não é passível, pois esta faculdade inicia seu processo a partir de um elemento anterior, já sedimentado na memória informacional.

Apreender esse novo tendo como ponto de partida o velho pressupõe, em Ferrara (1986, p. 32), um 'reconhecimento do velho e uma 'parada' perceptiva diante do novo. Esse descentramento da informação passou para a história das teorias artísticas com o nome de estranhamento".

As constantes estratégicas, então, têm o objetivo de causar no sujeito esse estranhamento, com vistas a retirar a automatização do comportamento comum. Para isso,

Persp. Online: hum \& sociais aplicada., Campos dos Goytacazes, 27 (10)1-21- 2020 seer.perspectivasonline.com.br 
conforme a autora, à eleição de uma dominante, que pode recair sobre qualquer traço indicial, ambicioso e de caráter estratégico, como som, luz, textura e cor.

Nas palavras de Lucrécia Ferrara:

A eleição de uma dominante desperta a atenção para o ambiente espacial, para o texto que nos envolve, porém ela é estratégica e metodologicamente ambiciosa. Em outras palavras, é operacional, porque dela depende a despasteurização do habitual, ou seja, tornar heterogêneo o homogêneo pela ênfase atenta a determinados índices, estimulados pela dominante. Hierarquiza-se a textura indicial e isto nos permite estranhar o ambiente e colocar em crise o hábito de ver, perceber ou usar (FERRARA, 1986, p. 33).

Condensando os caracteres envolvidos nas constantes estratégicas, a atenção é considerada seu cerne, sendo orientada por dois elementos, também básicos: a observação e a comparação. De modo resumido, a contextualização, o estranhamento e a dominante decorrem da observação, sendo fator de interação com o espaço não-verbal, no sentido de produzir uma leitura, despertando a comparação, a analogia, combinações, voluntária ou não, a outras estruturas.

A comparação, de maneira breve, permite criar/constatar equivalências inesperadas entre os índices, ainda que hierarquizados por uma dominante. Essas analogias, dentre os procedimentos estratégicos, são elementos mais diretamente responsáveis pela integração sensorial, a fim de superar o mundo independente dos sentidos.

Os procedimentos des-verbais, outra subdivisão dos procedimentos metodológicos indicados por Ferrara (1986, p. 34-35), se referem aos elementos práticos com função de auxiliar a atuação das constantes estratégias, tratando-se de técnicas operacionais.

Será através das técnicas escolhidas que, nas palavras de Ferrara (1986, p. 35), “se processará uma dissecação ocular, auditiva, olfativa, tátil num primeiro momento da abordagem, à comparação e, logo após, a uma recomposição daqueles elementos, de modo a explicitar as relações estruturais e analógicas que serão exploradas na leitura". A contextualização é uma iniciativa interessante, pois supõe o levantamento da memória ambiental encontrada a partir de documentação de arquivos, jornais, fotografias antigas. Conhecer propositalmente a história de determinado ambiente, através de seus usos e fatos, contribui para a produção profunda de uma analogia do presente.

Ao lado dessa memória, é necessário conduzir a busca para as informações múltiplas através do uso de técnicas que permitirão avaliar a dinâmica atual, na qual operam intercódigos, como gravações, fotografias, vídeos, desenhos e croquis. Através destas técnicas, capazes de captar instantes, a informação é retida, de modo a superar o mundo independente dos sentidos e estimular a analogia que permite apreender o ambiente ao redor, ensinando a ver mais e melhor. Concluindo seu pensamento sobre uma metodologia possível para a análise dos aspectos não-verbais - constantes estratégicas e procedimentos des-verbais - a autora explica:

\footnotetext{
A contextualização, o estranhamento, a eleição de uma dominante, a atenção, a ênfase, a observação, a comparação e a analogia, enfim, as constantes estratégicas já vistas, são condições de leitura não-verbal, mas esse produto só se manifesta, só explicita seu desempenho através do verbal, porque sua consistência, sua conviç̧ão alicerçam-se numa lógica argumentativa que é característica e distinta da linguagem verbal (...). Os códigos se comunicam e se explicam mutuamente. Esse é o destino das linguagens (FERRARA, 1986, p. 36).
}

Persp. Online: hum \& sociais aplicada., Campos dos Goytacazes, 27 (10)1-21- 2020 seer.perspectivasonline.com.br 
Assim, qualificando que o estudo do não-verbal suscita um produto verbal, visto que sua característica metalinguística não dispensa o registro oral e/ou escrito, para Coelho Netto (1984), o sentido deve ser buscado nos eixos que organizam o discurso arquitetural. E esse discurso não é autônomo, mas atravessado por outros discursos, e, portanto, deve-se considerar também o contexto imediato como determinante das condições de produção do discurso arquitetural.

A Etnografia, metodologia típica das ciências sociais, estuda os grupos da sociedade, suas características antropológicas, sociais e culturais, como define Duarte, a seguir:

\begin{abstract}
A Etnografia é a escrita do visível. A descrição etnográfica depende das qualidades de observação, de sensibilidade ao outro, do conhecimento sobre o contexto estudado, da inteligência e da imaginação científica do etnógrafo (...). O objeto da etnografia é esse conjunto de significantes em termos dos quais os eventos, fatos, ações, e contextos, são produzidos, percebidos e interpretados, e sem os quais não existem como categoria cultural (DUARTE, 2010, p. 5).
\end{abstract}

Duarte (2010, p. 5) em seu trabalho levanta questionamentos sobre a utilização da metodologia etnográfica para o estudioso da arquitetura e se este poderia contribuir com esta análise: "poderia remodelar seu olhar para captar a riqueza de informações emitidas ininterruptamente pelas ambiências das cidades?". A pesquisadora acredita "na possibilidade de acrescentar dados importantes, relacionados ao espaço construído, que poderiam se somar à descrição densa produzida por eles."

Deriva, portanto, da etnografia a análise etnotopográfica, defendida pelo Laboratório de Arquitetura, Subjetividade e Cultura (LASC), vinculado ao Programa de Pós-graduação em Arquitetura e Urbanismo da Universidade Federal do Rio de Janeiro, atualmente liderado pela professora Cristiane Duarte (2010, p. 5), citada anteriormente, "sendo voltado para a sistematização de metodologias de análise das ambiências, visando compreender relações identitárias e de imagens urbanas coletivas, assim como desvendar o espaço enquanto materialização das culturas e subjetividades”.

Carvalho (2013, p. 73) explica, ainda, que, “em meio à pesquisa etnotopográfica (...), é importante destacar que não só a visão deva ser privilegiada. Sons, cheiros, texturas, luminosidades compõem uma ambiência e precisam ser considerados".

Para Duarte (2010), muito frequentemente, quando é induzido a efetuar uma descrição densa de um contexto social, o arquiteto pesquisador não consegue ignorar sua observação do espaço construído, mas costuma perceber não só o lado objetivo da arquitetura, e sim, principalmente, as percepções que dela emanam.

O resultado desse processo, que trata de uma descrição participante, será constituído de variadas e incontáveis menções ao espaço, mas também estará repleto de observações relacionadas aos comportamentos e dinâmicas ocorridos no ambiente analisado. Assim a descrição se mostra mais completa, capaz de envolver ambiências e relevar questões de suma importância para o entendimento do universo cultural que se modifica e se recria no local de estudo (DUARTE, 2010). No momento em que a fotografia é utilizada como instrumento principal na realização de um trabalho etnográfico, Boni e Moreschi (2007) denominam de fotoetnografia, e explicam:

Persp. Online: hum \& sociais aplicada., Campos dos Goytacazes, 27 (10)1-21- 2020 seer.perspectivasonline.com.br 
A fotografia etnográfica pode estar inserida em trabalhos científicos, exposições ou diversos tipos de publicação. Pode ser caracterizada como objeto de estudo, pesquisa ou como mera ilustração. Esse tipo de trabalho contribui para que haja um resgate de informações relacionadas aos diferentes tipos de etnias. Além disso, compila dados de conhecimento, que podem servir como fonte de comparação anacrônica, posto que a cultura e os costumes das etnias estão sujeitos a transformações (BONI; MORESCHI, 2007, p. 138-139).

Numa brincadeira de palavras e termos, será realizada, então, uma etno-topo-fotografia: croquis, fotografias, filmagens, entrevistas e mapeamentos são meios importantes no objetivo de se alcançar uma descrição mais completa do visível e do invisível. Por tal motivo, as fotografias utilizadas neste trabalho serão apresentadas a seguir.

Tabela 1: Fotografias para a entrevista estruturada (autoria própria)

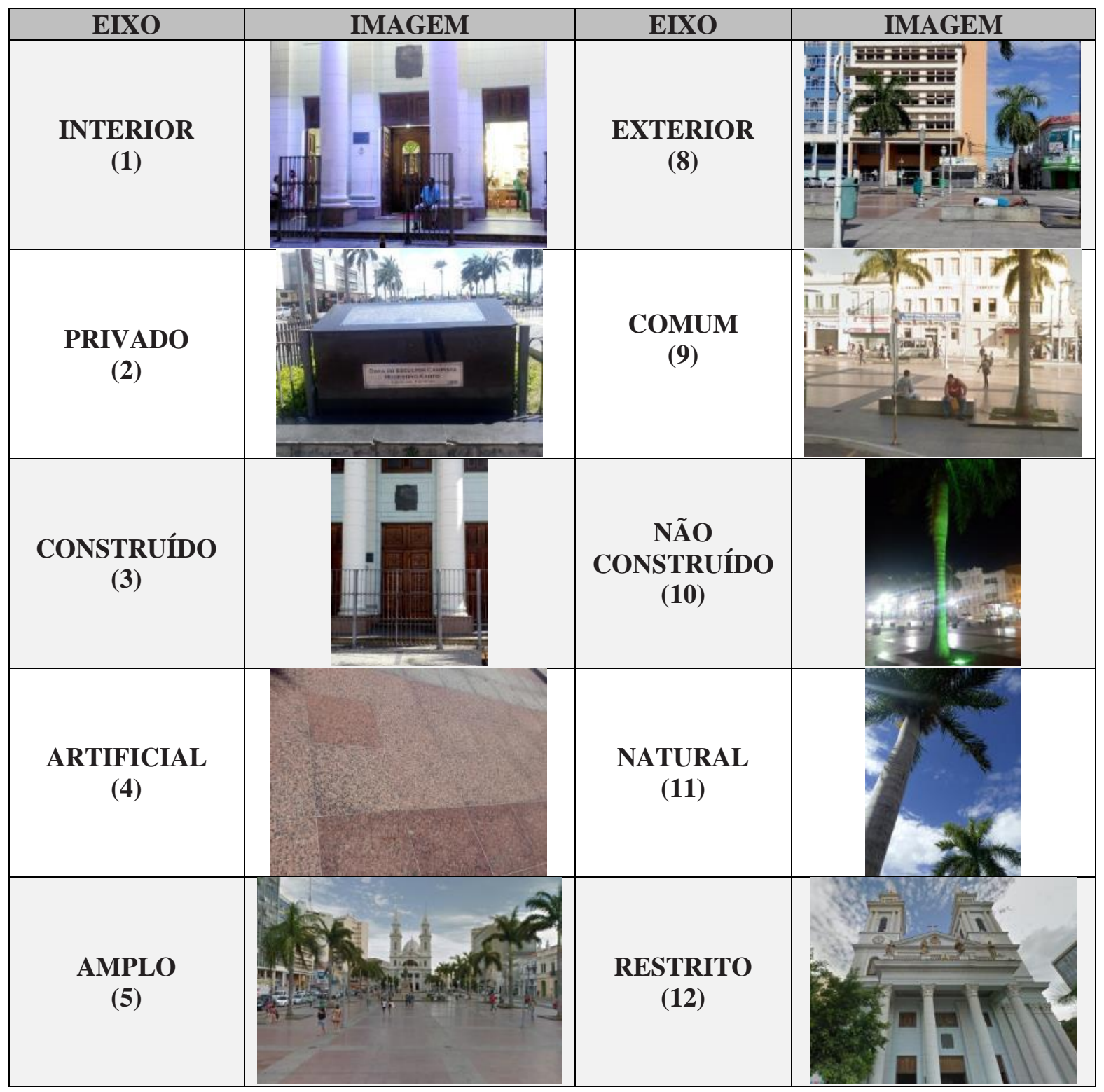

Persp. Online: hum \& sociais aplicada., Campos dos Goytacazes, 27 (10)1-21- 2020 seer.perspectivasonline.com.br 


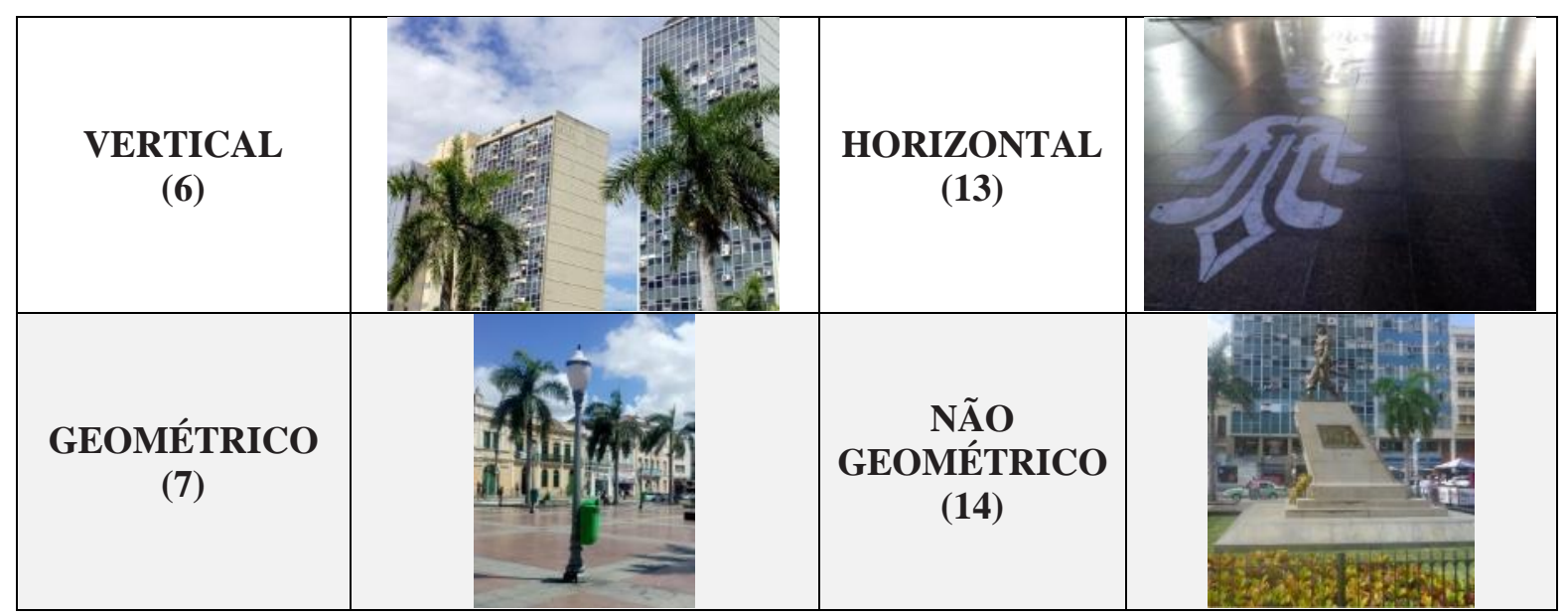

A ferramenta "Mapeamento das Manifestações" consiste em espacializar em plantabaixa as manifestações de afeto, as relações interpessoais ou qualquer outro evento social que ocorra em campo.

O que distingue o ser humano das demais espécies de seres vivos é sua capacidade racional e evolutiva na cognição. $O$ homo sapiens é o único ser vivo com aptidão para pensamento abstrato e condições de aprendizado inteligível - ser cognoscente. O processo de composição de conceitos, experiências, construção de conhecimentos, assimilação, aquisição, acomodação e equilíbrio somente se materializará com eficácia quando houver a presença de elementos fundamentais (atenção, memória, emoção e funções executivas) que incidirão como elos necessários para o processo (GOMES, 2018, p. 1).

O Mapeamento de Manifestações consiste em demonstrar, em geral, relações, movimentos, manifestações e estímulos e outros dados captados em campo. Esta ferramenta, apesar de parecer semelhante num primeiro momento à ferramenta anterior, tem uma proposta conceitual diferente, en que o pesquisador já parte de um desenho pronto do espaço e ali assinala interações comportamentais do indivíduo perante o meio (DUARTE, 2010).

Muitas pesquisas buscam elemento e dados quantitativos e contáveis para seus resultados e conclusões, entretanto, para o arquiteto pesquisador, melhor é expressar a realidade por meio de registros gráficos. Esses registros, por conseguinte, proporcionam levantar situações que sobressaltem e devem ser exploradas numa fase posterior da pesquisa.

Esta ferramenta foi usada, como exemplo, na pesquisa de Duarte, em que as manifestações de afeto ou desafeto pelos vizinhos das quadras do conjunto habitacional foram mapeadas. Da mesma forma, usando como fundo a planta de arranjos espaciais, Brasileiro (2007) mapeou as relações interpessoais em superposição às relações hierárquicas no funcionamento de uma empresa. Para elaboração dos Mapas de Manifestações, foram realizadas visitas à praça São Salvador em turnos diversos, com registros fotográficos com elementos que sejam capazes de apresentar a vivência urbana de acordo com a vitalidade real do espaço.

Persp. Online: hum \& sociais aplicada., Campos dos Goytacazes, 27 (10)1-21- 2020 seer.perspectivasonline.com.br 
Tabela 2: Turnos de Observação para o Mapa de Manifestações (autoria própria)

\begin{tabular}{|c|c|c|c|}
\hline Dias da semana & Manhã & Tarde & Noite \\
\hline Sábado / Domingo & \multicolumn{3}{|c|}{$\begin{array}{c}\text { Praça São Salvador } \\
\text { (geralmente no mesmo horário) }\end{array}$} \\
\hline Segunda-feira à quinta-feira & & \\
\hline Sexta-feira & & \\
\hline
\end{tabular}

A ferramenta "croqui de campo", segundo Duarte (2010), consiste em um produto gráfico da observação, formado por desenhos arquitetônicos, rabiscos, croquis e esquemas. Da mesma forma que o etnógrafo possui um diário de campo cheio de anotações, adota-se anotação por meio de desenhos e croquis, que é a expressão própria de arquitetos. Laplantine sugere:

(...) a descrição etnográfica é ao mesmo tempo direta na sua expressão e midiatizada por tudo o que permite ter acesso a ela (cartografia, fotografia, gravações, sem contar os croquis, as plantas, os esquemas gráficos, os quadrados, os retângulos, os triângulos, os círculos, os raios) e por todas as representações habituais das relações de parentesco que todo etnógrafo traça em seus cadernos (LAPLANTINE, 2005, p. 50-51).

Porém, os croquis de campo vão além de mera ilustração: se configuram na própria descrição. No momento em que o pesquisador desenha o que vê, está num processo em que se conscientiza do que lhe chama a atenção e descreve, por meio de desenhos, suas observações. Carvalho afirma sobre os croquis de campo:

São elementos indispensáveis numa comunicação arquitetural estabelecida entre o observador etnógrafo-arquiteto e o ambiente, (...) através da qual é possível representar emoções, intensidades de estímulos, fluxos, dentre outros componentes relacionados à ambiência (CARVALHO, 2013, p. 18).

Podem ser utilizadas cores para facilitar a apreensão de características que lhes sejam próprias, como concentrações, formas de uso, aspectos funcionais, fluxos e zonas/massas de conflitos espaciais. Esse estudo gráfico contribui para a descrição espacial dos eventos e sua verificação física no ambiente.

Os instrumentos metodológicos descritos utilizados nesta pesquisa formam uma importante base na análise urbana que associa arquitetura e etnografia. Entretanto, a visão do pesquisador, apesar da ousadia em estar dentro e perto do objeto de estudo, pode não ser suficiente para reproduzir em totalidade o que o outro percebe do espaço. Nesse sentido, considera-se a entrevista importante para se aproximar cada vez mais do objeto de estudo e do modo como este é apropriado pelos indivíduos.

Definida por Bingham e Moore (apud Sommer, 1997) como um relato verbal voltado para o esclarecimento de um objetivo pré-estipulado, as entrevistas ratificam a assimilação de informações a respeito das pessoas, de seus sentimentos, sensações, crenças e valores, o que, para alcançar os objetivos, também precisa de estímulo pelo pesquisador, sempre atento às pistas mais sutis do respondente.

Carvalho (2013) utilizou, em seu trabalho, duas tipologias de entrevista: a estruturada e a semiestruturada, considerando a primeira baseada no roteiro impresso, programado previamente, com dedicação de pouco tempo às respostas, enquanto a segunda se baseia em roteiro ou esquema básico, com a função de orientar o pesquisador. No caso da pesquisa de

Persp. Online: hum \& sociais aplicada., Campos dos Goytacazes, 27 (10)1-21- 2020 seer.perspectivasonline.com.br 
Carvalho (2013, p. 82), “as entrevistas possibilitaram desde o esclarecimento de dúvidas em relação aos cenários analisados, a questionamentos inerentes às ambiências noturnas, o que contribuiu para uma leitura mais completa e menos individual do objeto de estudo".

Na concepção de Triviños (1987, p. 146), a "entrevista semiestruturada tem como características questionamentos básicos que são apoiados em teorias e hipóteses que se relacionam ao tema da pesquisa". Os questionamentos possibilitam frutos a novas hipóteses surgidas a partir das respostas dos informantes. O foco principal seria colocado pelo investigador-entrevistador.

Complementa o autor, afirmando que a entrevista semiestruturada "favorece não só a descrição dos fenômenos sociais, mas também sua explicação e a compreensão de sua totalidade", além de manter a presença consciente e atuante do pesquisador no processo de coleta de informações (TRIVIÑOS, 1987, p. 152).

Para alcançar os objetivos dessa pesquisa, foram realizadas adaptações no roteiro de Carvalho (2013), não apenas pela distinção entre as temáticas abordadas, mas pelo alvo almejado. Tais adaptações foram baseadas no trabalho de Mucelin e Bellini (2007, p. 224), com a "utilização das imagens para investigar a percepção de determinados fragmentos desse contexto urbano [que] nos levou a desenvolver uma técnica de investigação baseada em imagens fotográficas", denominada Jogo da Percepção:

\footnotetext{
É nesse pressuposto da imagem fotográfica, de permitir a alguém observar recortes fixados da realidade, da percepção habitual dos fatos, que imputamos à fotografia o crédito de ser um instrumento facilitado rdo estudo da percepção ambiental. Como ícone, a fotografia permite a um observador ler circunstâncias de um contexto, permitindo que a realidade ou fragmento se revele de maneira tão corriqueira que pode ser pensada como significante, ou elemento revelador da realidade (MUCELIN; BELLINI, 2007, p. 229).
}

Expósito (2005, s/p) considera que a imagem "evidencia o caráter incompleto de nossa percepção, deixando aparecer uma ausência ou uma perturbação. [...] Aparece assim, de novo, o processo de estranhamento, que nos faz distanciar daquilo que vemos". A fotografia, logo, é um instrumento sígnico perceptivo, que tem a qualidade de expressar situações de singularidade de hábitos.

Os autores do "Jogo de Percepção" explicam: atividade de análise perceptiva é realizada com um conjunto de imagens previamente escolhidas sobre um determinado tema ou objeto de estudo, para estimular e evidenciar a percepção do participante do jogo sobre a temática. Ferrara (1999) afirma que o ser humano desenvolve uma capacidade que consiste em associar imagens sobre algo, combiná-las parcial ou totalmente, sempre obedecendo a um hábito mental de associação de ideias.

A escolha das palavras-chave da entrevista semiestruturada se fiou nos sete eixos da produção de sentido na arquitetura, de Coelho Netto (1986), na busca de substantivos que se correlacionem com os pares, a fim de captar os sentidos imbricados no espaço urbano, através da estrutura semântica proposta pelo autor, quais sejam:

Persp. Online: hum \& sociais aplicada., Campos dos Goytacazes, 27 (10)1-21- 2020 seer.perspectivasonline.com.br 
Tabela 3: Palavras-chave por Eixo de Sentido na Arquitetura (autoria própria)

\begin{tabular}{|c|c|c|c|}
\hline EIXO & PALAVRAS-CHAVE & EIXO & PALAVRAS-CHAVE \\
\hline interior & $\begin{array}{c}\text { sossego } \\
\text { mistério }\end{array}$ & exterior & $\begin{array}{c}\text { liberdade } \\
\text { vulnerabilidade }\end{array}$ \\
\hline privado & $\begin{array}{c}\text { sufocado } \\
\text { segurança }\end{array}$ & comum & $\begin{array}{c}\text { intimidade } \\
\text { curiosidade }\end{array}$ \\
\hline construído & $\begin{array}{c}\text { respeito } \\
\text { criatividade }\end{array}$ & não construído & $\begin{array}{c}\text { medo } \\
\text { coragem }\end{array}$ \\
\hline artificial & $\begin{array}{c}\text { falsidade } \\
\text { sonho }\end{array}$ & natural & $\begin{array}{c}\text { delicadeza } \\
\text { vida }\end{array}$ \\
\hline amplo & $\begin{array}{c}\text { justiça } \\
\text { orgulho }\end{array}$ & restrito & $\begin{array}{c}\text { claridade } \\
\text { desligamento }\end{array}$ \\
\hline vertical & $\begin{array}{c}\text { necessidade } \\
\text { consequência }\end{array}$ & horizontal & $\begin{array}{c}\text { continuidade } \\
\text { estabilidade }\end{array}$ \\
\hline geométrico & $\begin{array}{c}\text { ordem } \\
\text { sequência }\end{array}$ & não geométrico & $\begin{array}{c}\text { loucura } \\
\text { ousadia }\end{array}$ \\
\hline
\end{tabular}

Com base nas fotografias registradas nas visitas, foram escolhidas as palavras-chave, que foram numeradas e encadernadas num álbum para que fosse levado a campo a fim de realizar as entrevistas semiestruturadas in loco, de modo a gerar os resultados adiante, além das análises possíveis.

\section{RESULTADOS E DISCUSSÃO}

Percorrer caminhos através da pluralidade e heterogeneidade espaço-temporal da cidade, adicionado às relações de afeto/memória entre indivíduo e meio, fazem da produção de sentido arquitetural algo complexo, mais vinculado à experiência individual-cultural e na relação com a construção do Lugar. Manifesta-se, portanto a necessidade de um percurso metodológico mais fluido e experimental, na proposta de uma semiótica aplicada, que possa ser moldada e reconstruída a partir das descobertas em campo.

Primeiramente, nas visitas ao entorno da Praça São Salvador, houve um processo de reconhecimento espacial, em termos de praticar a caminhada em passadas curtas e lentas, de modo a apreciar cada imagem, atuando perceptivamente sobre alguns elementos compositores da imagem urbana, tais como aglomeração e espaçamento entre pessoas, seus deslocamentos ou tempo de permanência, aspectos climáticos e de conforto térmico/lumínico, percepção sonora e olfativa, expressões de afeto entre pessoas ou pessoa-lugar e as situações de perigo ou risco. Através dessa caminhada sensorial - tratada nos textos como etnotopografia - e das anotações do observado nos blocos de notas e Croquis de Campotorna-se possível elaborar o Mapeamento das Manifestaçõesde ambas as praças, permitindo cruzar as sensações experimentadas em cada turno.

A etnotopografia aconteceu em dias típicos para a cidade, evitando feriados, período de veraneio, dias festivos ou de chuva, por exemplo, pois tendem a caracterizar novos aspectos - até cabíveis de investigação - às praças, entretanto, excepcionais ao cotidiano, distanciando do objetivo desta pesquisa. As figuras a seguir retratam algumas percepções da pesquisadora após as visitas de observação e anotações relevantes, nos chamados croquis de campo.

Persp. Online: hum \& sociais aplicada., Campos dos Goytacazes, 27 (10)1-21- 2020 seer.perspectivasonline.com.br 


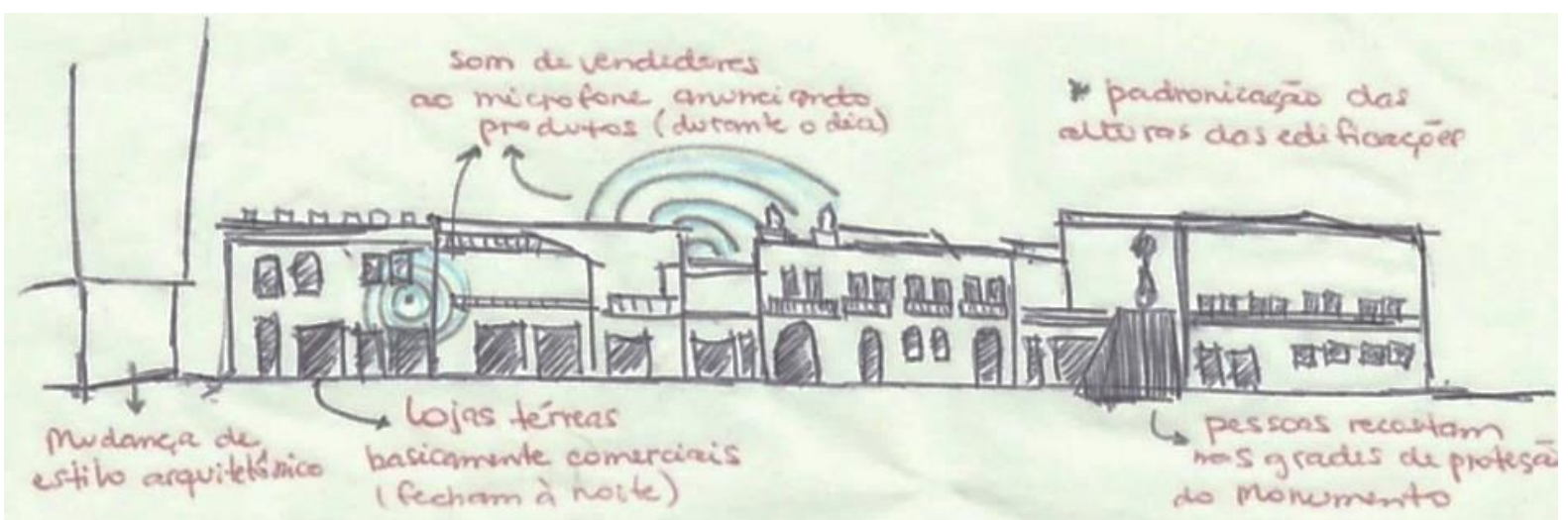

Figura 1: Croqui 1 - lateral direita, próximo ao Museu (Autoria própria, 2017)

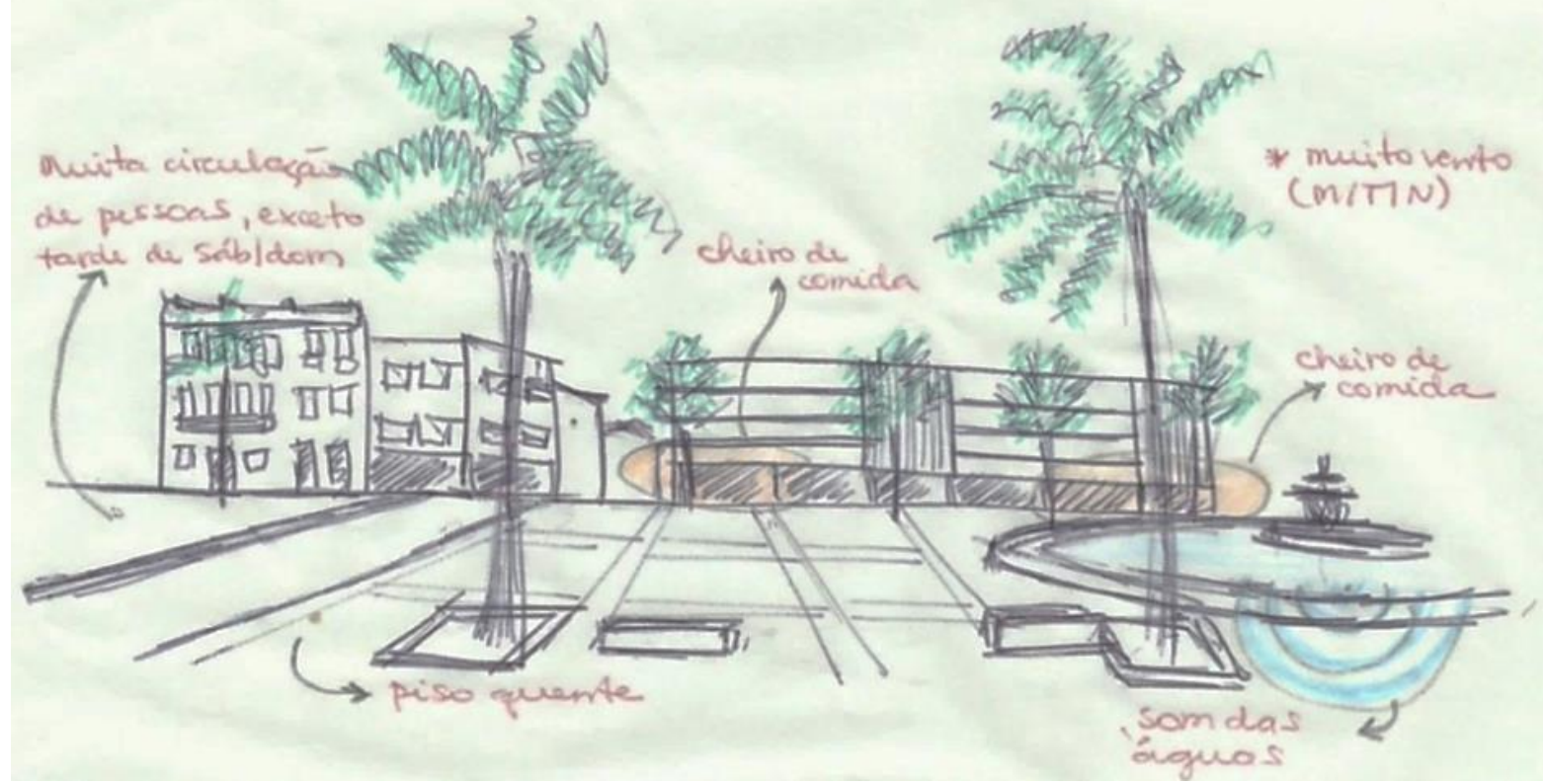

Figura 2: Croqui 2 - lateral direita, próximo ao chafariz (Autoria própria, 2017)

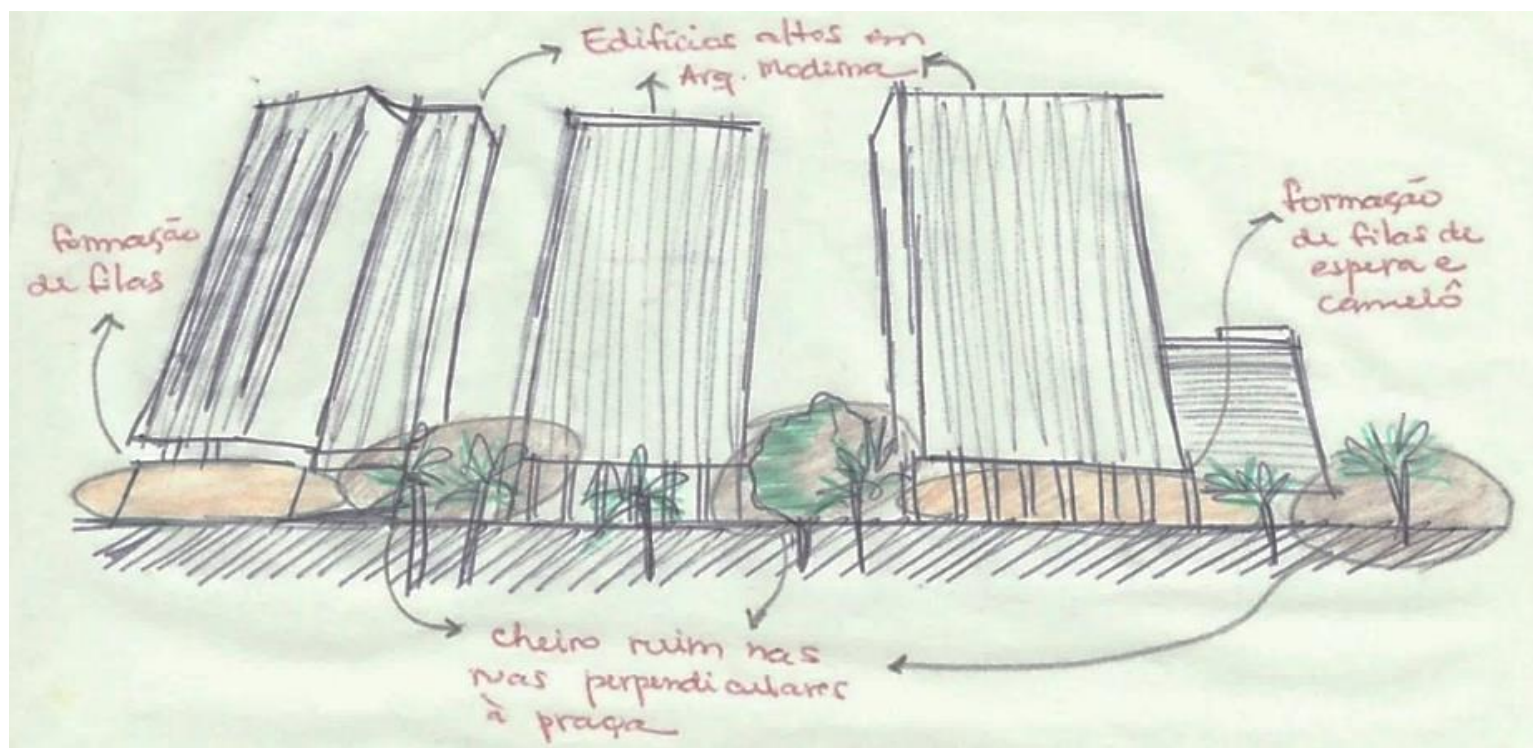

Figura 3: Croqui 3 - lateral esquerda, próximo ao chafariz (Autoria própria, 2017)

Persp. Online: hum \& sociais aplicada., Campos dos Goytacazes, 27 (10)1-21- 2020 seer.perspectivasonline.com.br 


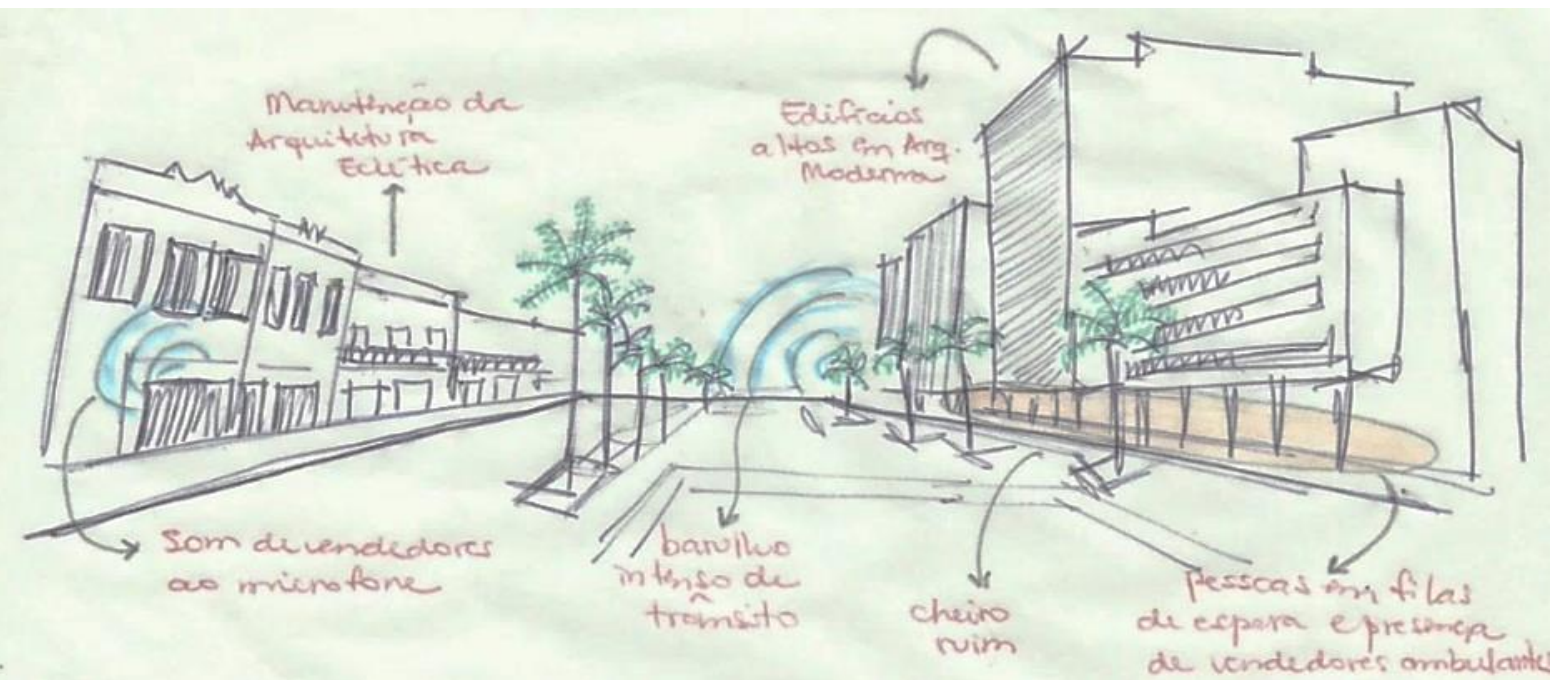

Figura 4: Croqui 4 - vista da catedral para o rio (Autoria própria, 2017)

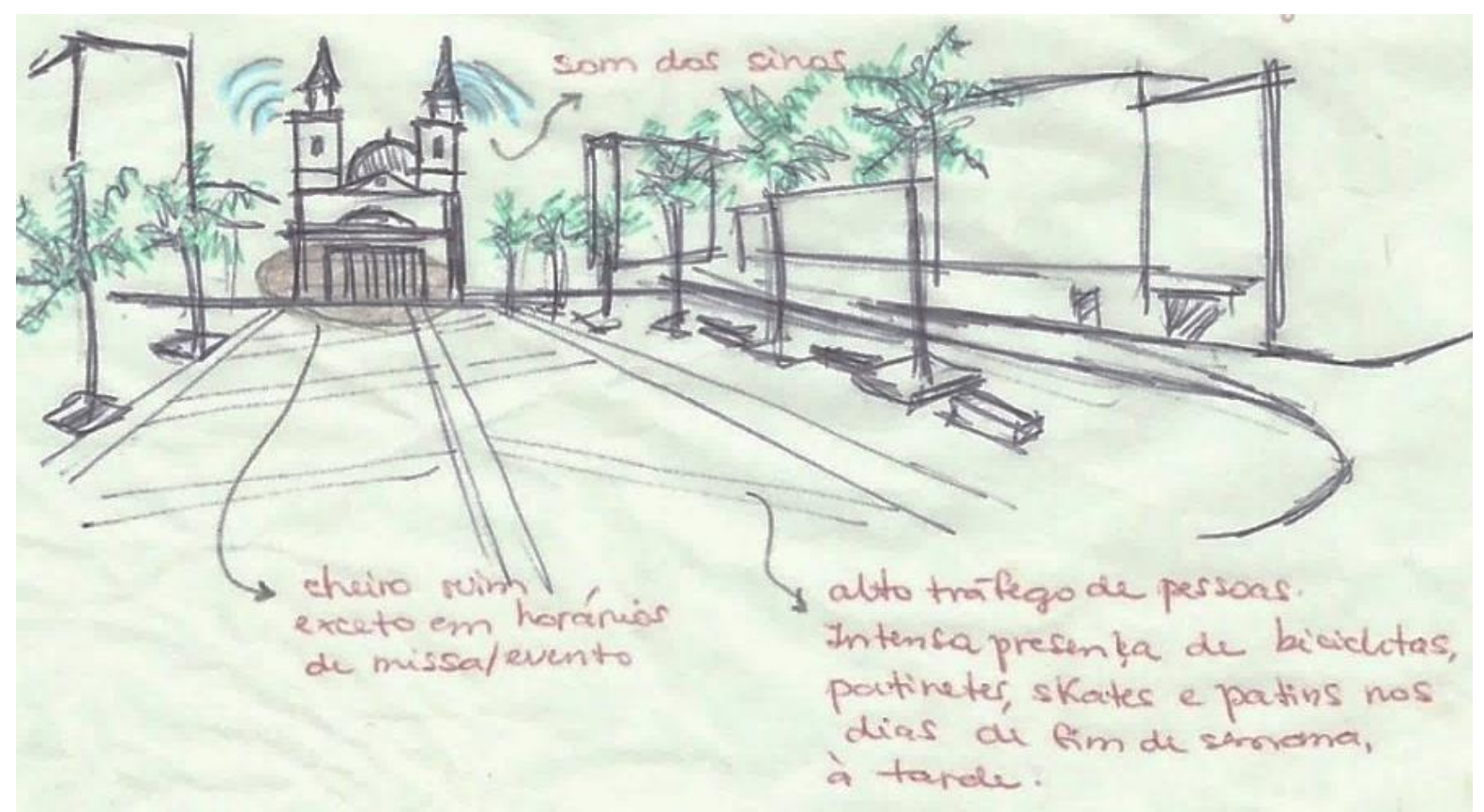

Figura 5: Croqui 5 - vista da catedral (Autoria própria, 2017)

Tendo em mãos os croquis, foi possível seguir para o desenvolvimento dos "Mapeamentos das Manifestações" na Praça São Salvador, adicionando ao mapa da praça as sensações percebidas durante das visitas, registradas em croquis, textos e fotografias, como circulação e permanência de pessoas, temperatura local, sombreamento/claridade, odores, pontos de perigo e de sonorização.

Persp. Online: hum \& sociais aplicada., Campos dos Goytacazes, 27 (10)1-21- 2020 seer.perspectivasonline.com.br 


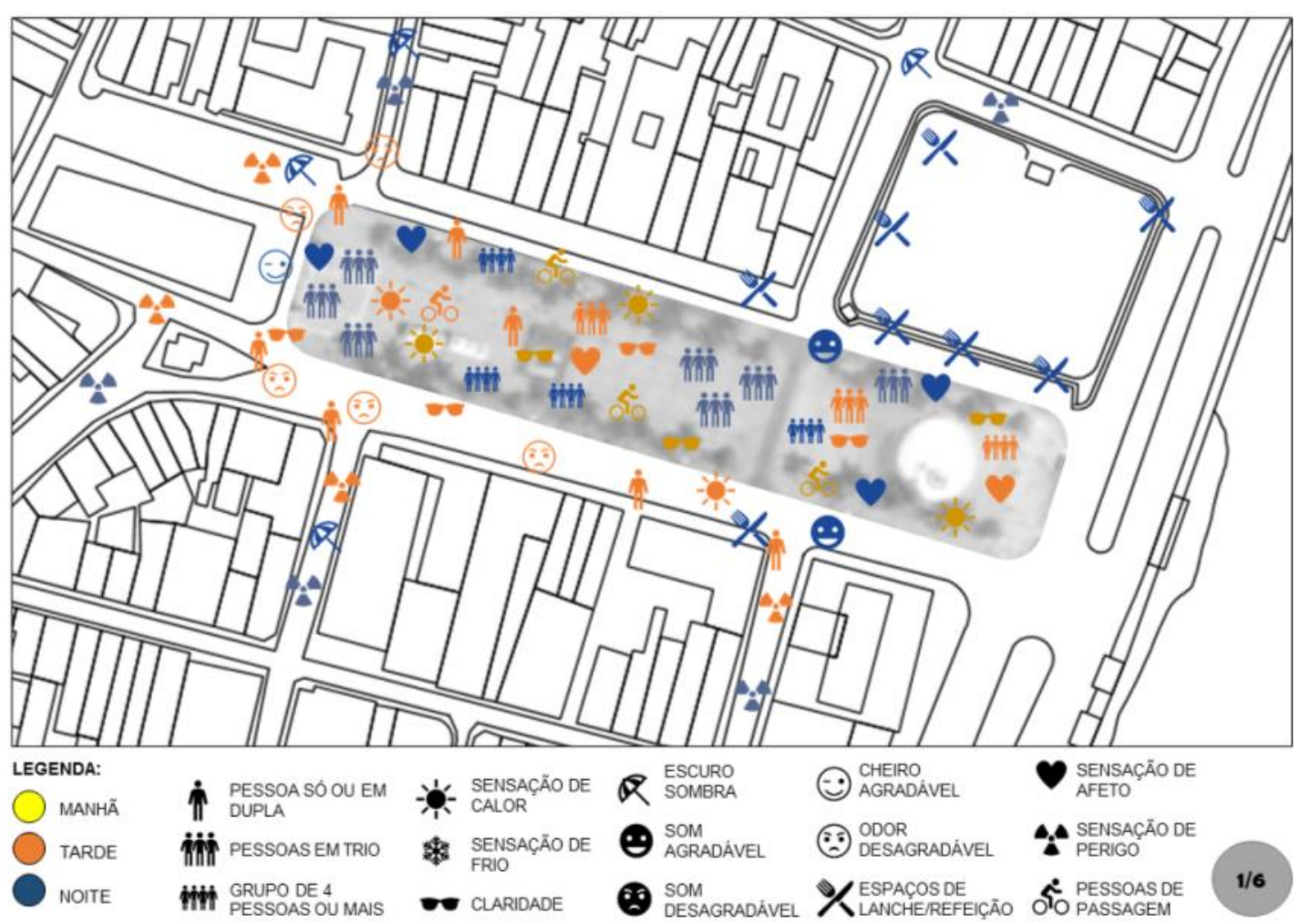

Figura 6: Manifestações Sábado e Domingo - Praça São Salvador - 2017 (autoria própria)

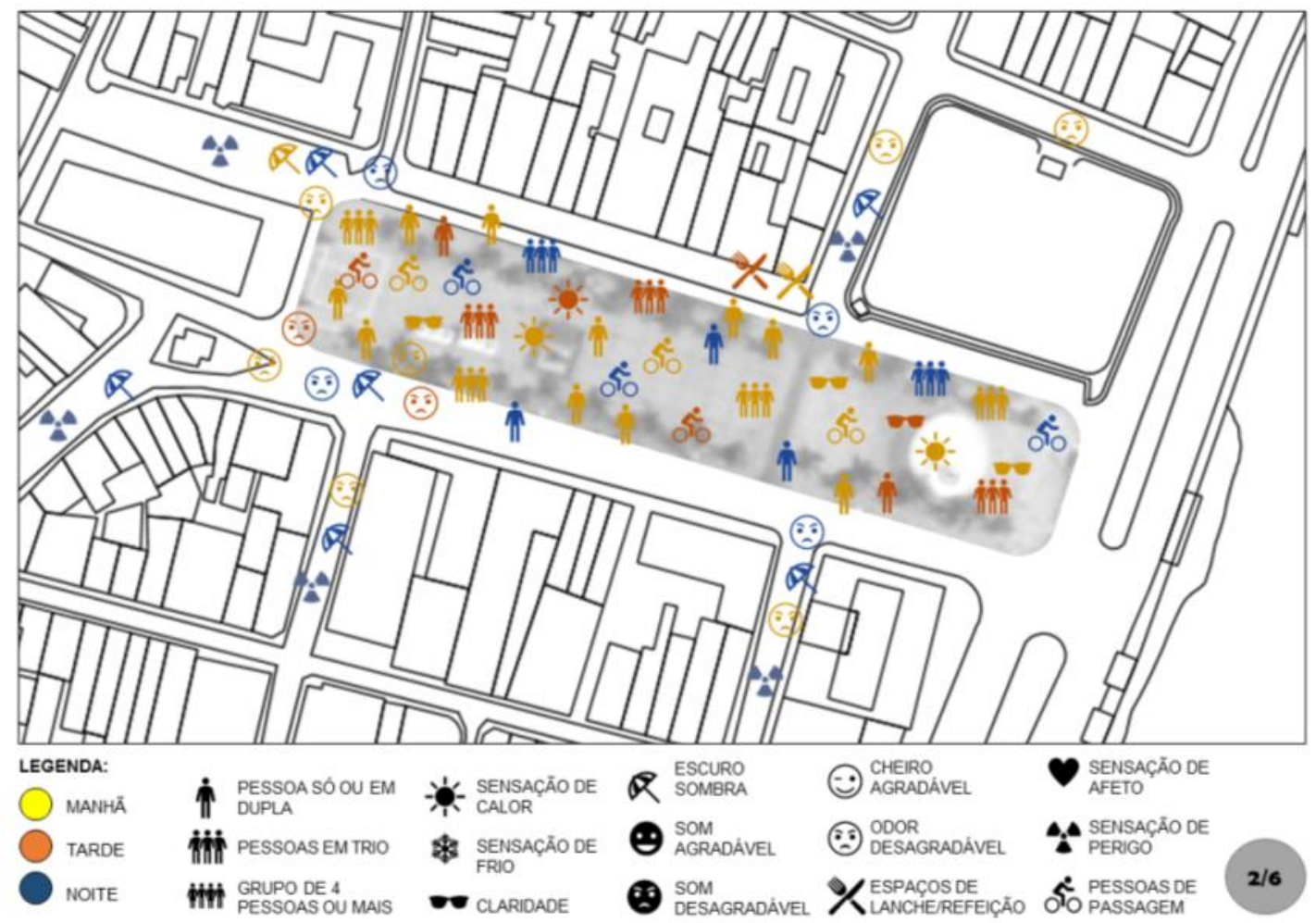

Figura 7: Manifestações Segunda a Quinta-feira - Praça São Salvador - 2017 (autoria própria)

Persp. Online: hum \& sociais aplicada., Campos dos Goytacazes, 27 (10)1-21- 2020 seer.perspectivasonline.com.br 


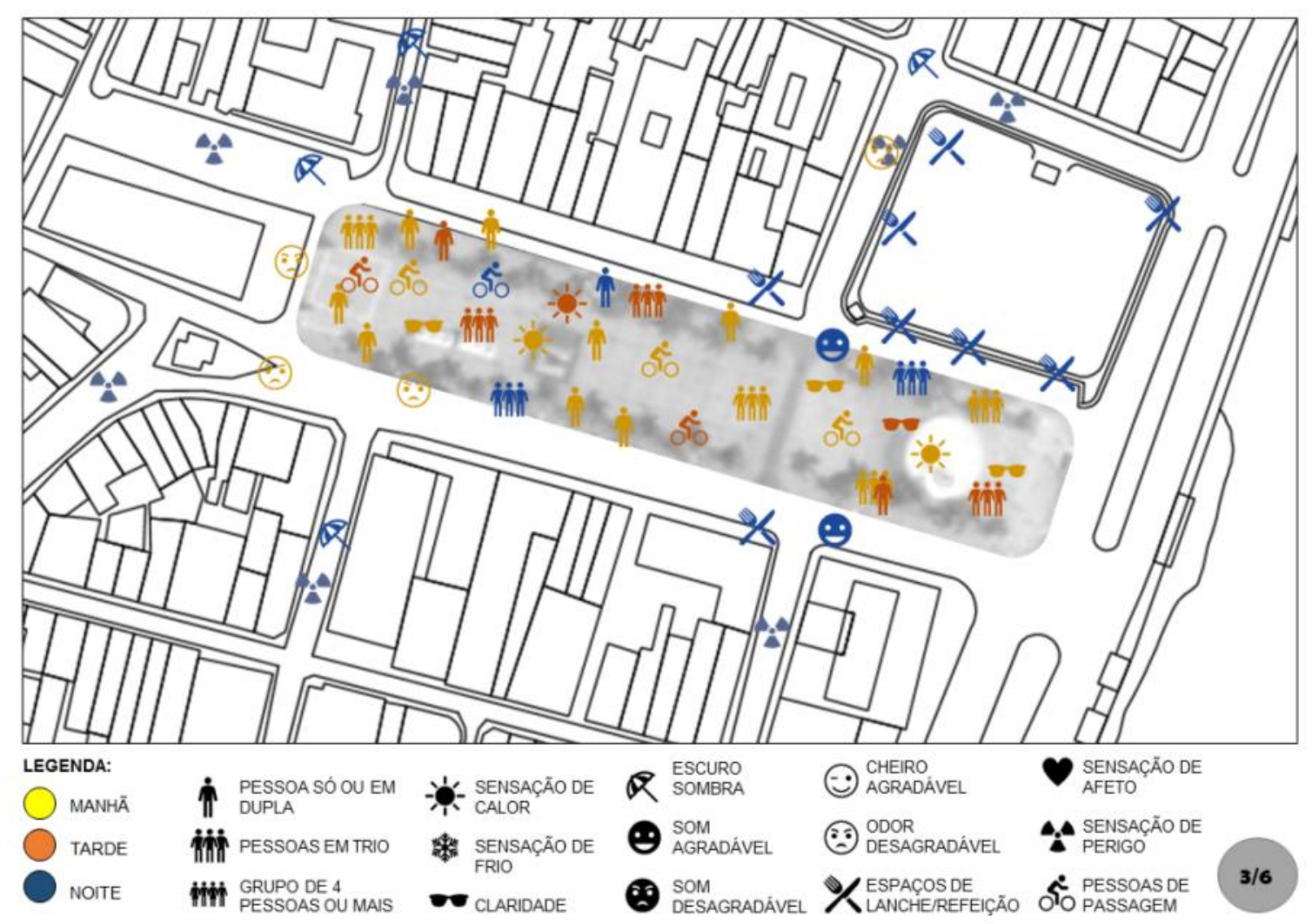

Figura 8: Manifestações Sexta-feira - Praça São Salvador - 2017 (autoria própria)

Foi possível observar a elevada presença de pessoas na praça em todos os dias da semana, em sua maioria aglomerada e em movimento, ou seja, grupos de pessoas (duplas, trios e quartetos) que estão juntas e se deslocam pelo espaço, como famílias e grupos de amigos. Ressalta-se nesse quesito a ausência de pessoas na praça no domingo de manhã, percebendo apenas algumas pessoas de bicicleta trafegando e atravessando o local.

Em se tratando de conforto térmico e lumínico, a praça possui iluminação natural intensa da manhã ao início da noite, o sol incidente sobre todo o seu passeio e bancos. As palmeiras, apesar de grandiosas, pouco colaboram para a melhoria da condição do microclima presente.

É certo que à noite seu aspecto árido favorece a sensação de segurança, se estiver dentro da praça, pois nas ruas ao redor, perpendiculares ao seu tecido, a sensação de perigo e risco é notável em todos os dias da semana. As palmeiras altas não impedem a iluminação artificial dos postes, propiciando um ambiente claro e de visualização total dos acontecimentos nas proximidades.

Em termos de percepção sonora, no período de segunda-feira a sexta-feira, seja pela manhã, à tarde ou à noite, não foi possível pontuar os sons como agradáveis ou incômodos, visto que se trata de som ambiente, em que conversas, trânsito e vozes dos vendedores se misturam, não causando qualquer desconforto. Nos fins de semana, o som ambiente se altera para conversas informais e de crianças se divertindo. Nas noites de sábado e domingo, os bares do entorno propiciam um ambiente de música ao vivo de voz e violão. O único som que se faz marca no dia a dia é o soar dos sinos da Catedral Santíssima São Salvador.

Acerca das sensações olfativas, o aspecto desagradável desse quesito se fez presente

Persp. Online: hum \& sociais aplicada., Campos dos Goytacazes, 27 (10)1-21- 2020 seer.perspectivasonline.com.br 
quase em todos os dias e turnos, predominando o odor forte de urina e chorume. Nota-se que nos sábados e domingos à noite o odor desagradável se ausenta. Infere-se que, devido às atividades religiosas de domingo, há uma manutenção da calçada em frente ao acesso principal, num processo de limpeza que atue contra o odor ruim no local.

Não se percebem relações de afeto - tratado aqui como as interações e as relações sociais em meio urbano - na Praça São Salvador, no decorrer dos dias da semana. Porém, nas tardes de sábado e domingo, há indicações de afeto entre famílias e casais, assim como no fim da missa, quando as pessoas se cumprimentam e acenam para outras pessoas.

Este artigo usa para esta abordagem a possibilidade de incursão. Ou seja, é essencial que o pesquisador seja capaz de compreender o objeto de estudo. Para tanto, foram entrevistadas aleatoriamente nove pessoas, todas residentes em Campos dos Goytacazes - RJ, questionadas também sobre alguns aspectos pessoais formadores de um perfil para o respondente, tais quais idade, gênero, nível de escolaridade e assiduidade na Praça São Salvador. Não se torna exigência um mínimo de pessoas entrevistas para verificação das estatísticas por ser tratar de pesquisa qualitativa de abordagem sensorial, voltado a eixos semióticos, onde a amostragem não é obrigatoriamente um objeto de crédito às pesquisas etnográficas.

A distribuição por gêneros dos entrevistados foi levantada, sendo $67 \%$ de público feminino e $33 \%$ restantes de público masculino. Também foram registrados dados para a distribuição por faixa etária dos entrevistados em que a maioria dos entrevistados (34\%) tem entre 18 e 25 anos de idade, seguido de $22 \%$ dos participantes com idade entre 31 e 40 anos e todos os demais possuem a mesma distribuição de $11 \%$, com idades entre 26-30 anos, 41-50 anos, 51-60 anos e 61-70 anos.

Acerca da assiduidade, estabeleceram-se os critérios temporais, como frequência diária, semanal, mensal, bimestral ou anual. Assim, é possível comparar as porcentagens de assiduidade aos locais. Verificou-se que 33\% dos entrevistados frequentam diariamente a Praça São Salvador, seguidos dos entrevistados que, somados, incumbem-se de $22 \%$ das frequências semanais e mensais nesta mesma praça e outros $44 \%$ a frequentam bimestralmente.

Para melhor observação dos dados baseados nas palavras-chave elencadas ao observar as fotografias relativas a Praça São Salvador, elaborou-se a Figura 9, na qual é possível relacionar as palavras-chave por frequência nas respostas em relação aos eixos organizados do sentido do espaço.

Persp. Online: hum \& sociais aplicada., Campos dos Goytacazes, 27 (10)1-21- 2020 seer.perspectivasonline.com.br 


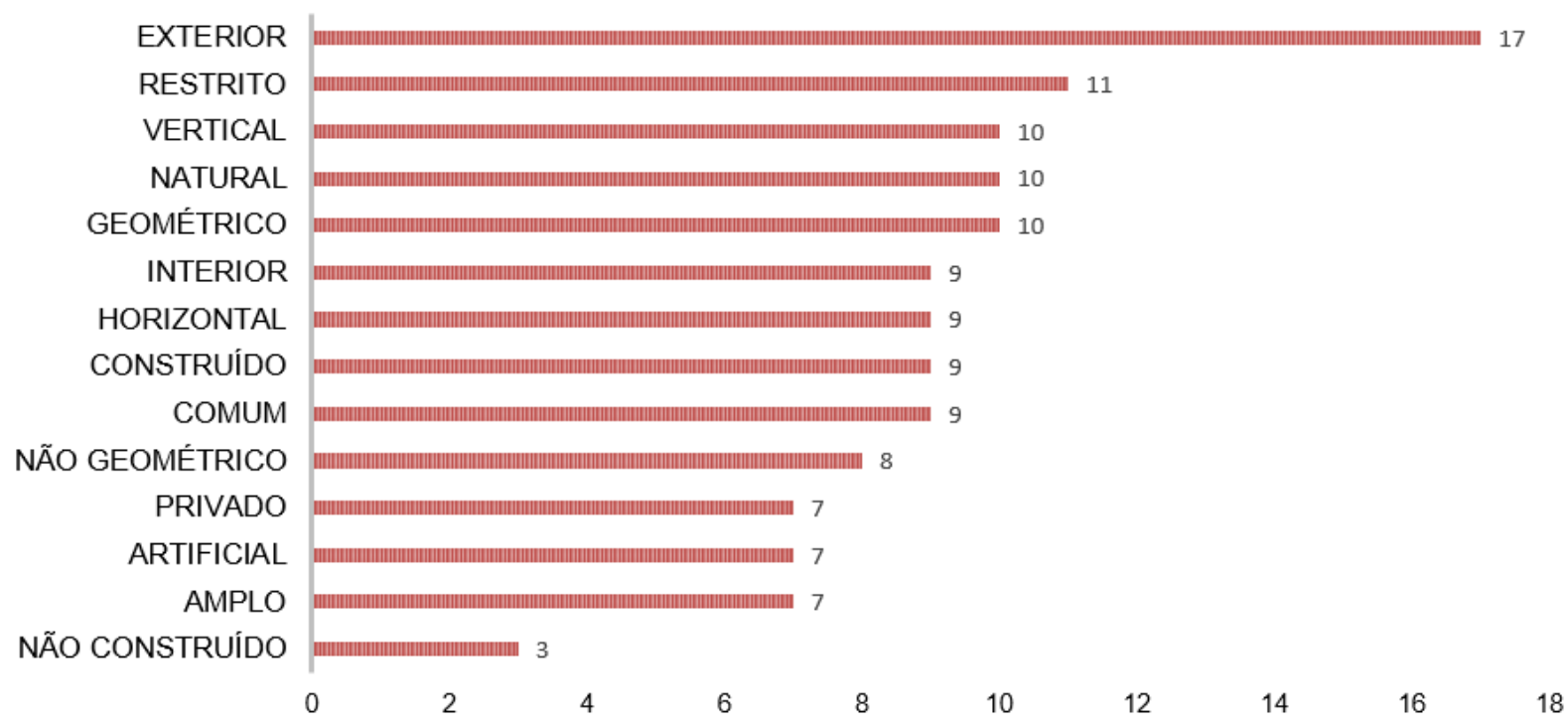

Figura 9: Respostas por eixos organizadores do sentido do espaço (Própria autora)

Na Figura 9, percebe-se que o eixo exterior possui 13,5\% das referências voltadas a Praça São Salvador, seguido de 8,7\% ocupados pelo eixo restrito; posteriormente, empatados com 7,9\%, seguem os eixos vertical, natural e geométrico; com 7,1\% empatam os eixos interior, horizontal, construído e comum; com 6,3\% está o eixo não geométrico. Empatados com 5,6\% estão os eixos privado, artificial e amplo e, finalmente, está o eixo não construído, com $2,4 \%$.

A seguir, a Figura 10 apresenta as frequências de respostas por palavra-chave, permitindo o início das análises sobre a Praça São Salvador:

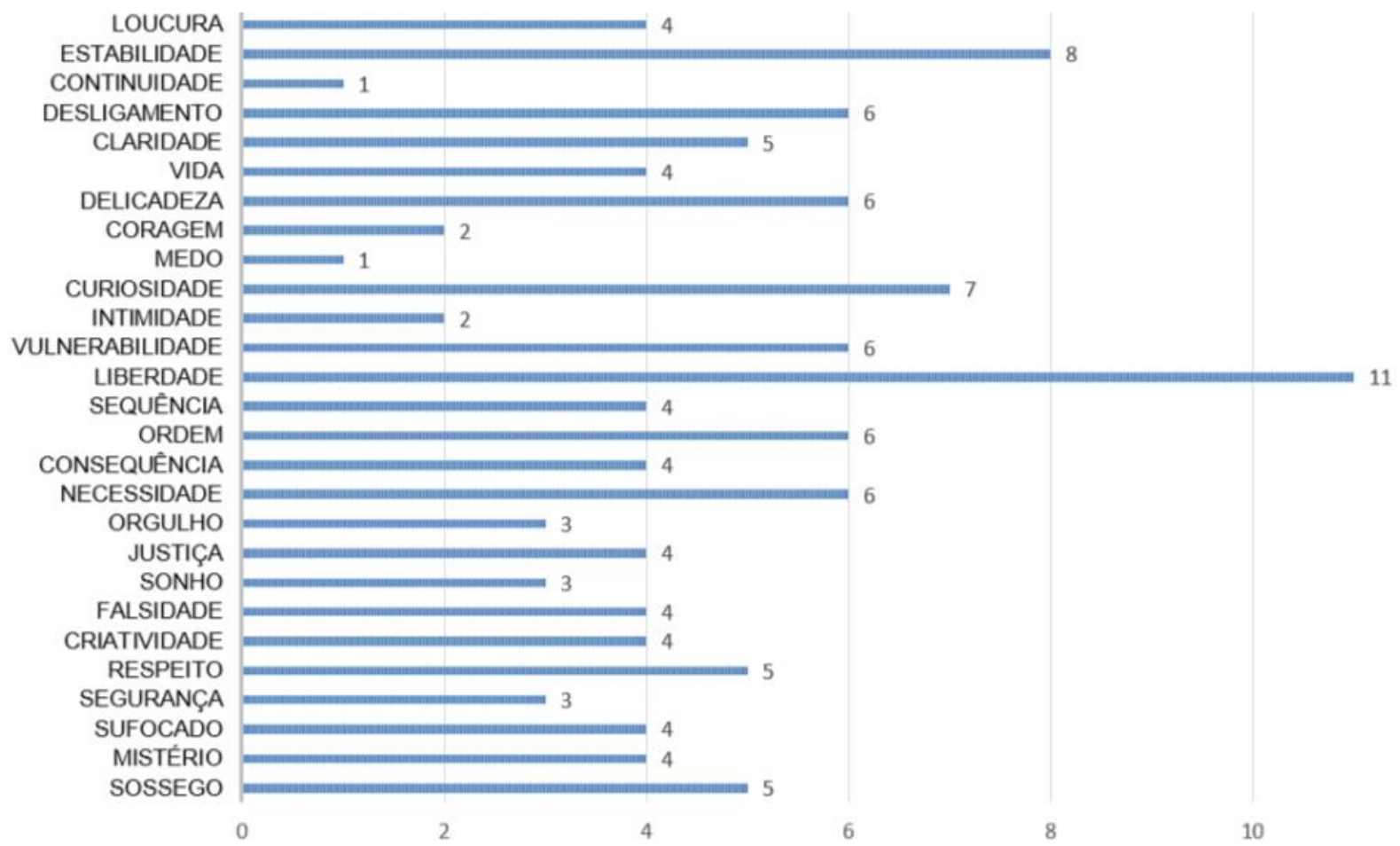

Figura 10: Respostas por palavras-chave - Praça São Salvador (Própria autora)

Persp. Online: hum \& sociais aplicada., Campos dos Goytacazes, 27 (10)1-21- 2020 seer.perspectivasonline.com.br 
Sobre o espaço exterior $\mathrm{x}$ interior salienta-se o caráter além da dualidade casa versus não-casa, como elabora Coelho Netto (1984), ao afirmar que é necessário se desvencilhar dessa concepção abrindo espaço para novos conceitos. Tal fato se mostra no alto índice de respostas liberdade $(8,7 \%)$, nas entrevistas sobre as fotografias da Praça São Salvador, sendo possível perceber essa ressignificação do lugar de abrigo como interior e seu inverso como exterior, visto que a característica de liberdade poderia ser usufruída dentro de casa (em termos de poder agir como quiser dentro de um espaço de sua propriedade, livre para seu arbítrio) ou na cidade (onde as pessoas se posicionam além dos fatores residenciais, como economia doméstica, problemas familiares, saúde, e tantos mais), sendo livres na sua atuação, principalmente no espaço onde a maioria está de passagem. Também o que foi representado pela palavra vulnerabilidade $(4,8 \%)$, em casos de desconforto espacial que o exterior, por vezes, permite sentir, seja sobre si próprio ou sobre algo observado. Já o espaço interior se fez presente nas respostas sossego (4\%) - acerca da tranquilidade - e mistério (3,2\%), ao se tratar de algo incomum ao espectador.

O espaço restrito esteve vinculado às palavras-chave claridade e desligamento, que segundo Coelho Netto, estão vinculadas a proteção, intimidade, secreto. Caracterizada como Espaço Restrito, a Praça São Salvador foi considerada como espaço claro no aspecto da segurança que a claridade propõe, onde tudo estaria facilmente visível, possuindo $4 \%$ das respostas. O termo Desligamento foi considerado como fator de particularidade, posto que o usuário, ao se desligar de certas considerações e se despreocupar, implica ao espaço um caráter de intimidade com o mesmo. Infere-se que uma pessoa se permite desligar do entorno quando já o conhece, imaginando o que esperar. Tais fatores estão vinculados à intimidade que cada um traz para o espaço. $4,8 \%$ dos respondentes caracterizaram algumas imagens da Praça São Salvador nesse gênero organizador do espaço. O espaço amplo, caracterizado pelos termos justiça $(3,2 \%)$ e orgulho $(2,4 \%)$, faz referência à magnitude que o espaço propõe, que, com organização bem-sucedida não causa sensação de angústia do vazio, por exemplo.

Os eixos vertical, natural e geométrico possuíram a mesma porcentagem na frequência de respostas, representados por um par de palavras-chave, cada eixo. O eixo vertical faz referência à temporalização do espaço como afirma Coelho Netto (1984, p. 80), "instrumentos básicos contra o tédio e opressão arquitetônica" representada pelas palavras consequência $(3,1 \%)$ como acontecimento advindo de uma decisão tomada anteriormente - e necessidade $(4,7 \%)$ - como acontecimento necessário e sem volta - na entrevista. O eixo natural (Fotos 4 e 11) esteve representado pelas palavras delicadeza $(4,8 \%)$ e vida $(3,2 \%)$. Nesse eixo, o espaço não-construído se integra ao tecido urbano, mantendo suas características de espaço disponível, um espaço de desobrigações. O espaço geométrico(fotos 7 e 14) trata do artificial opondo-se ao orgânico, nas linhas retas, e certo geometrismo do espaço, representado pelas palavras ordem e sequência, com 4,8\% e 3,2\% respectivamente. seus respectivos opostos, os eixos horizontal, artificial e não geométrico, foram representados pelos pares de palavraschave continuidade/estabilidade $(0,8 \%$ e $6,3 \%)$, falsidade/sonho $(3,2 \%$ e $2,4 \%)$ e loucura/ousadia (ambos com 3,2\%).

O Eixo Construído x Não Construído, representado pelos duetos Respeito (4\%) / Criativo $(3,2 \%)$ e Medo $(0,8 \%) /$ Coragem $(1,6 \%)$ refere-se à participação dos cidadãos no espaço em análise, seja por ações políticas ou sociais, de inclusão ou exclusão de pessoas/atividades. Percebe-se que as ações no espaço construído são mais efervescentes, se comparada ao espaço não construído.

Para finalizar esse quesito, o eixo comum x privado refere-se aos diferentes usos e aos diferentes sentidos, conforme cultura e época. O eixo comum é balizado pelas palavras-chave

Persp. Online: hum \& sociais aplicada., Campos dos Goytacazes, 27 (10)1-21- 2020 seer.perspectivasonline.com.br 
intimidade $(1,6 \%)$ e curiosidade $(5,6 \%)$ - aspectos percebidos quando um espaço se mostra de todos. O eixo privado se apresenta através dos termos sufocamento $(3,2 \%)$ e Segurança $(2,4 \%)$ - ao estabelecer o espaço privado como algo seguro, mas também de imposição e sufocamento sobre outros espaços.

\section{CONCLUSÕES}

A investigação ocorreu segundo uma linha de orientação metodológica que mescla a arquitetura, a sociologia e a semiótica, enredada aqui como etnotopografia, meio pelo qual se fazem registros perceptuais do espaço, majorados com o auxílio de fotografias, croquis e mapas - linguagem própria do arquiteto -, porém sob os ensinamentos sociológicos para observar um espaço além de somente vê-lo ou descrevê-lo superficialmente. Tais elementos, somados aos conhecimentos de semiótica são passíveis de análise a ponto de indicar caracteres que satisfaçam aos objetivos desse trabalho. Trata-se aqui, portanto, de encontrar elementos baseados em sensações individuais que alimentem a formação de uma imagem da cidade que se forma-reforma-transforma a cada olhar.

A Praça São Salvador se apresenta cotidianamente como lugar de ligeireza, de passos rápidos, firmes, inconstantes, de muitas idas e vindas, de algo envolvido pelo calor do comércio, dos sons de promoções e convites de visitas às lojas, de panfletagem e outros apelos de comerciantes. Essa pesquisa permitiu vislumbrar a Praça São Salvador em ângulos diversos da visão comum do observador rotineiro, manifestando uma transversalidade que só se mostra ao parar da caminhada, ao ter a atenção desviada do rumo e voltada para seus pormenores. Pormenores não em tamanho ou de algo às escondidas: a copa das palmeiras, o desenho no piso, a sombra dos prédios modernos em seu piso liso, os diferentes usos do banco, os monumentos para os homenageáveis, sua metade de arquitetura eclética e sua metade de arquitetura moderna... Todos esses pormenores são alvos simples de um olhar, que ao atentar, para o destino final da passagem, não se percebem.

As praças possuem diversas facetas, conforme os dias da semana, eventos e acontecimentos em seu entorno, comportamento dos cidadãos, assim como atividades exercidas nas proximidades, que influenciam sua rotina a cada hora. A intensa transversalidade urbana permite as mais inúmeras análises e conclusões, dependendo do ponto de vista do pesquisador.

\section{REFERÊNCIAS}

BONI, P. C.; MORESCHI, B. M. Fotoetnografia: a importância da fotografia para o resgate etnográfico. In: Doc On-line, n. 3, Dez. 2007, p. 137-157. Disponível em: http://www.doc.ubi.pt/03/artigo_paulo_cesar_boni.pdf. Acesso em: 07 jan. 2017.

BRASILEIRO, A. B. H. Rebatimentos espaciais de dimensões sócio-culturais: ambientes de trabalho. Tese de doutorado. Rio de Janeiro: UFRJ/FAU, 2007.

CARVAlHO, N. M. Ambiências Noturnas: arquiteturas e subjetividades em cenários urbanos cariocas. Dissertação de Mestrado. Rio de Janeiro: UFRJ/FAU, 2013.

COELHO NETTO, J. T. A construção de sentidos na arquitetura. 2. ed. São Paulo:

Persp. Online: hum \& sociais aplicada., Campos dos Goytacazes, 27 (10)1-21- 2020

seer.perspectivasonline.com.br 
Perspectiva, 1984.

DUARTE, C. R. Cultura, subjetividade e experiência: dinâmicas contemporâneas na Arquitetura. In: Anais do I Encontro Nacional da Associação Nacional de Pesquisa e Pósgraduação em Arquitetura e Urbanismo. Rio de Janeiro, 29 de novembro a 03 de dezembro de 2010.

EXPÓSITO, A. M. O tempo suspenso: fotografia e relato. Disponível em: http://www.studium.iar.unicamp.br. Acesso em: 07 jan. 2017.

FERRARA, L. D’A. Leitura sem palavras. São Paulo: Ática, 1986.

FERRARA, L. D'A. Olhar periférico: informação, linguagem, percepção ambiental. São Paulo: EDUSP, 1999.

GOMES, F.; RIBEIRO, A. L. B.; GOBETI, L. C.; SEABRA, L. F. D. Processo de aprendizagem eficaz: olhar e ações psicopedagógicas diante da interdisciplinaridade cognitiva científica. Humanas \& Sociais Aplicadas, v. 8, n. 22, 26 nov. 2018. Disponível em: https://ojs3.perspectivasonline.com.br/humanas_sociais_e_aplicadas/article/view/1645.

Acesso em: 12 fev. 2020.

LAPLANTINE, F. A descrição etnográfica. Trad. João Manuel R. Coelho e Sérgio Coelho. São Paulo: Terceira Margem, 2004.

MANHÃES, L. S. P.; FAIAL, C. S. G.; FERNADES, F. C.; FAIAL, L. C. M.; PIRES, L. M.V.; TAVARES, C. M. M. Mapa conceitual sobre interdisciplinaridade na construção do conhecimento. Humanas \& Sociais Aplicadas, v. 8, n. 22, 26 nov. 2018. Disponível em: https://ojs3.perspectivasonline.com.br/humanas_sociais_e_aplicadas/article/view/1621.

Acesso em: 12 fev 2020.

MUCELIN, C. A.; BELLINI, L. M.. A percepção ambiental urbana com uso de imagens fotográficas: um instrumento semiótico denominado Jogo de Percepção. In: Discursos fotográficos, v. 3, n. 3, p. 221-248. Londrina, 2007. Disponível em: http://www.uel.br/revistas/uel/index.php/discursosfotograficos/article/view/1501/1247.

Acesso em: 07 jan. 2017.

SANTAELLA, L. O que é semiótica. São Paulo: Brasiliense, 2007.

SOMMER, B.; SOMMER, R. A practical guide to behavioral research: tools an d techniques. Nova York: Oxford University Press, 1997.

TRIVIÑOS, A. N. S. Introdução à pesquisa em ciências sociais: a pesquisa qualitativa em educação. São Paulo: Atlas, 1987.

Persp. Online: hum \& sociais aplicada., Campos dos Goytacazes, 27 (10)1-21- 2020 seer.perspectivasonline.com.br 